\title{
Exploring Social Support Needs amongst Caregivers of Learning Disabilities
}

Syukriah Mohd Zailani, Nur Saadah Mohamad Aun \& Arena Che Kasim

To Link this Article: http://dx.doi.org/10.6007/IJARBSS/v12-i1/12177

DOI:10.6007/IJARBSS/v12-i1/12177

Received: 07 November 2021, Revised: 11 December 2021, Accepted: 26 December 2021

Published Online: 18 January 2022

In-Text Citation: (Zailani et al., 2022)

To Cite this Article: Zailani, S. M., Aun, N. S. M., \& Kasim, A. C. (2022). Exploring Social Support Needs amongst Caregivers of Learning Disabilities. International Journal of Academic Research in Business and Social Sciences, 12(1), 1445-1453.

\section{Copyright: (c) 2022 The Author(s)}

Published by Human Resource Management Academic Research Society (www.hrmars.com)

This article is published under the Creative Commons Attribution (CC BY 4.0) license. Anyone may reproduce, distribute, translate and create derivative works of this article (for both commercial and non0-commercial purposes), subject to full attribution to the original publication and authors. The full terms of this license may be seen at: http://creativecommons.org/licences/by/4.0/legalcode

Vol. 12, No. 1, 2022, Pg. $1445-1453$

Full Terms \& Conditions of access and use can be found at http://hrmars.com/index.php/pages/detail/publication-ethics 


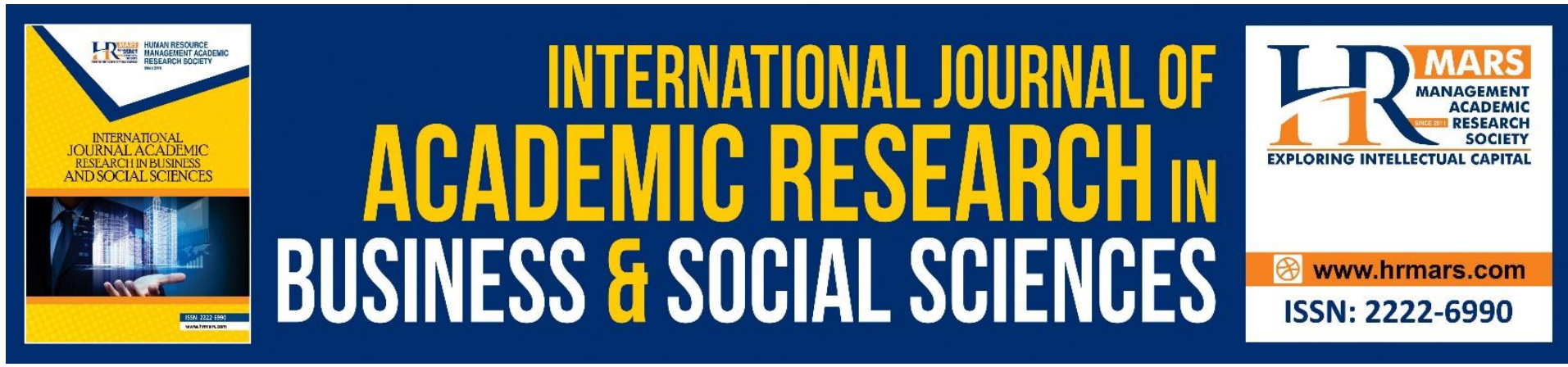

\title{
Exploring Social Support Needs amongst Caregivers of Learning Disabilities
}

\section{Syukriah Mohd Zailani, Nur Saadah Mohamad Aun \& Arena Che Kasim}

Social Work Program, Center for Research in Psychology and Human Well-Being,

Faculty of Social Sciences and Humanities, Universiti Kebangsaan Malaysia, 43600 Bangi, Selangor, Malaysia

Corresponding Author Email: n_saadah@ukm.edu.my

\begin{abstract}
The social support needs is very important for caregivers of learning disabilities and the role of social workers in ensuring that the needs of caregivers are met to ensure wellbeing. Receiving social support allows care arrangements to take place better for the well being of caregivers and learning disabilities. Failure to get social support needs will create problems such as emotional disorders resulting in impaired mental health and selfconfidence. Past studies on caregiver social support needs have focused more on studies on social support needs in general. The main purpose of this study was to explore the social support needs of caregivers with learning disabilities. The design of this study was qualitative. Four informants were selected based on purposive sampling method among caregivers with learning disabilities at one of Community Rehabilitation Center (CRC) in Klang Valley area. The interview protocol used was formed based on previous studies. Informants were interviewed online and all recorded data were transcribed using thematic analysis. The results of the study found that the need for social support was based on the learning problems being cared for along with the age of their children.
\end{abstract}

Keywords: Social Support, Caregivers, Learning Disabilities, Community Rehabilitation Center, Qualitative

\section{Introduction}

According to the Malaysia Persons with Disabilities Act (2008), disable individual is a person with long-term physical, mental, intellectual, or sensory impairments that when interacting with various barriers, can restrict their full and effective participation in society. According to Social Welfare Department Report (2018) has shown that the disabled registered with the Social Welfare Department in 2017 was 453,258 people. The physical disabled category recorded the highest enrolment at 35.2 percent, followed by the learning disability category $(34.8 \%)$, and the vision category (8.9\%). The speech category recorded the lowest enrolment at 0.5 percent. Therefore, the number of disabled people stated shows that the number of caregivers who take care of the disabled and this can disrupt the family system because of the burden they experience. This is because, informal care according to Aun et al (2012) refers 
to unpaid individuals who take on the role of caring for family members who are unable to take care of themselves in some or all aspects involving physical and emotional activities. Caregiving does not involve purely physical care, but it also involves financial matters, knowledge, mental strength and the ability of caregivers to manage their care so as not to cause conflict on any party. Moreover, the caregiving to the disabled who need full care in order to benefit both parties.

\section{Literature Review}

According to Zakaria et al (2019) such social support includes parents, friends and people around him. They also noted that lack of social support would create psychological problems such as depression, loneliness and anxiety. In fact, adequacy in social support will have a huge positive impact on an individual's life. Social support also refers to the variety of materials and emotions received by others. For material social support, it means material or material assistance given by others to an individual. For example, financial assistance given by a friend if we are having financial problems. For emotional social support, give advice and words of encouragement to improve the functionality of someone who is in a sad state or facing problems. For example, family members advise adolescents on problems related to their fights with friends at school and peers who advise on romance problems (Brannon \& Feist, 2004; Mahpis \& Akhir, 2020).

According to the study of Aun \& Abdullah (2015), most of the literature has proven that social support is able to help relieve the stress of informal caregivers and in turn successfully improve the quality of life of them and the individuals they care for. According to them, social support is emotional and financial support either from their nuclear and developmental family members or from their close neighbours. The stress experienced will subside a little when other family members help and understand, both materially and emotionally. A study by Amin et al., (2016) showed that most of those with disabilities get great support from parents and other family members because they have disabilities. However, due to their physical disabilities, there is an internal conflict between the child with disabilities and the parents, thus affecting their psycho-emotional development. This even creates a negative feeling between the family relationship that is a feeling of mutual hatred between the disabled child and his mother. In fact, there are also those who experience conflict with siblings because of parental attention given more to their disabled child. Thus, this shows that full family support has a great impact on creating a harmonious life.

\section{Caregivers of People with Learning Disabilities}

Caregiving can take place formally or informally. Formal care is more specific to any form of care provided in an institution and performed by specific individuals who have been given specific training to perform the role of care. In the context of the social relationship between the patient and the caregiver, usually the formal caregiver has no family relationship or friendship with the individual being cared for. Informal care is care provided by the non-public sector, such as private, voluntary, third sectors such as family members, neighbours, and community members. According to Christin (2015), children with disabilities require roundthe-clock care as they are unable to manage themselves compared to other normal children. In addition, the process of caring for the disabled is very challenging for mothers as they must provide basic needs such as feeding, bathing, and cleaning the stool because the disabled child is not able to manage themselves (Sivabalan et al., 2018). 
A study by Aun et al (2012) stated that informal care refers to unpaid individuals who take on the role of caring for family members who are unable to care for themselves in some or all aspects involving physical and emotional activities. This individual is called an informal caregiver. Caregiving does not involve purely physical care, but it also involves financial matters, knowledge, mental strength and the ability of caregivers to manage their care so as not to cause conflict on any party. Moreover, the care of the disabled who need full care in order to benefit both parties. Caregiving also is not only referring to woman but across gender (Mohamad et al., 2018). Caring for a child with a disability is an important challenge for most parents, especially if the disability is due to a rare disease. Parents find it difficult to get relevant information from family members, relatives or friends. This causes the level of stress encountered may be higher. The level of stress may be less if there are family members who help and cooperation between parents/guardians with medical officers or the hospital such as medical social work officers. Caring for the disabled is not an easy task because of discrimination and stigma against them. The assistance and support are important prerequisites for the disabled to participate in community development. The lack of necessary and appropriate support causes the disabled to have to depend on family members. This causes both parties to not be able to actively participate in productive activities and activities.

\section{Research Methodology}

For this study, researchers have used a qualitative approach to explore the social support of caregivers with learning disabilities and the role of social workers in helping caregivers obtain such social support. Qualitative research can help researchers understand more deeply about social support. The study that has been conducted meets the characteristics of qualitative research detailed by Merriam (1997) which is the first, focusing on understanding in depth what social support needed caregivers and at the same time understanding the role of social workers in providing assistance to caregivers of learning disabilities. Second, the selection of study involvement is purposeful in order to obtain as much data or information as possible. Third, this study takes a case study approach that examines the events that occur in the life of caregivers of learning disabilities. A qualitative approach based on case study design is a commonly used approach because it is capable of supporting a more in -depth and more detailed investigation for each case. It aims to study the background profile and social support needs of caregivers with learning disabilities. The study also involved data collected based on one or more study informants. The researcher will use observational methods for concepts that are less clearly stated by the informant.

\section{Findings and Discussion}

Disable person is a person who needs special and careful care by looking at the types of learning disabilities they faced. It is well known that among the disabled categorized in Malaysia are such as visual, hearing, physical, learning disabilities, speech, mental and various disabilities. As such, the issue of informal care has become the choice of caregivers due to traditional practices practiced by some families. A study by Aun et al (2012) who stated that most families on average perform their lifelong care function because their members need care either special or special care because there are young children, sick or disabled members and elderly parents. If one examines each of the stated levels and understands about the need for informal care this is the family's need for support from others, be it members of the nuclear family themselves, extended family members or family members 
themselves. Support is divided into two types of non-physical support such as health care, care during illness, day care, leisure, communication, where to complain and others. Meanwhile, physical support such as the provision of mobility, communication equipment, transportation, shelter, food, home furnishings, clothing and financial assistance.

The study of Amin et al (2016) in turn noted that previous studies found that many family members reported experiencing difficulties and complex issues in providing care and support to children with disabilities (Santamaria et al., 2012). For example, siblings of children with disabilities reported that they had difficulty forming family relationships with their disabled sister/brother/sister.

\section{Informant Profile}

In this study, the researcher has interviewed four informants named A, B, C and D. Profile data regarding these informants were obtained based on interviews that were conducted online. There are several components that have been determined by the researcher, namely gender, age, marital status, and period of care. Several ethics were observed throughout the conduct of the interviews and details of the interview information as well as recordings were not disclosed except for research purposes only.

Table 1 Informant Profile

\begin{tabular}{cccccc}
\hline Guardian & Gender & Age & $\begin{array}{c}\text { Marriage } \\
\text { status }\end{array}$ & $\begin{array}{c}\text { Types of } \\
\text { Learning } \\
\text { Disabilities }\end{array}$ & Period of care \\
\hline A & Female & 48 & Married & Slow Learner & 23 years old \\
B & Female & 38 & Married & Autism & 5 years \\
C & Male & 57 & Married & Autism & 24 years old \\
D & Female & 44 & Married & Down & 6 years \\
& & & & Syndrome & \\
\hline
\end{tabular}

Table 1 is the background information of the informants which includes gender, age, marital status, locality of residence and duration of care of caregivers in children with disabilities. Most of the informants interviewed were female, that is, three female and one male. In addition, all informants held the status of being married and in the age range of 38 years to 57 years.

\section{Social support needs of caregivers with learning disabilities}

Based on the interviews conducted with all the informants, the researchers found that the social support needed by caregivers with disabilities varies depending on the needs and issues of disabilities they face. Among the social support required by each informant are as follows:-

\section{i- Emotional Support}

This theme is often said by informants. This is because based on the study of Mohamad \& Rosdi (2018) stated that in general, parents who have children diagnosed with Autistic Spectrum Disorder (ASD) have recorded higher levels of stress than parents who have children with problems other developments. The results of Davies 'study found that parents with children with ASD had this led to higher levels of depression, anxiety, somatic (unrelated direct effects) and loss of a family 
function. In addition, fathers often use the word stress when making statements about raising a child with ASD. The following is an excerpt stated by the informant during the care of children with learning disabilities:

"... He's close to all his siblings. It's just that some of his siblings are angry because he kind of likes to repeat people's words, like the same sentence." (Informant A)

In contrast, informant B who takes care of learning disabilities's child in the Autism category. According to a study from Amin et al., (2020) proved that children with disabilities (MP) need careful care and treatment because they are so in need of attention. This statement is supported by informant $B$ as follows:

"... I have to quit my job after Haziq reaches 2 years old, I can't let people say me time with friends, can't go out shopping, everything can't be because he will stick with me for 24 hours." (Informant B)

Due to the pressure faced by informant B due to the need for close care for the care of learning disabilities, there are several ways for the informant to calm the situation. Therefore, this proves that caregivers with disabilities need emotional support in order to create well -being on behalf of caregivers and children with disabilities. The following is the informant's statement:

"... My youngest brother, sometimes 3, 4 times I meet in a month. That's all, I chat, sometimes he takes care of Haziq for a while, because Haziq doesn't want to be with people very much, with my youngest brother, he's okay. Managing my son has many challenges, sometimes it disrupts my career and my emotions a bit. also disturbed. " (Informant C)

\section{ii-Instrumental Support}

Instrumental support is also the main support for some informants involved with the care of learning disabilities, this is because, each problem faced provides different expenses. When viewed from the aspects of social support such as instrumental support that exists to meet the physical needs of their children such as food, clothing, shelter, children's health and children's expenses for school sessions. There were only 2 informants out of 4 who needed instrumental support.

"... He's the only problem of learning, there are no other problems that need treatment that need to buy other things, he's just normal."

"... It's not a big problem, it's just that he doesn't know how to read, the rest is all self-management he does himself, so he doesn't work at all and sit with me, so it's like there's no problem at all." (Informant A)

The following is the statement of informant $A$ who is the mother of a child with learning disabilities. According to the informant, his son did not bring any problems because all the self management was not done by him. In fact, according to the respondent, his son only has learning problems that involve speaking and writing as well as reading. This is because, this disabled child is already 23 years old. Therefore, all therapy has been stopped and only focuses on the skills in the life of informant A's child. The following is informant A's statement to support this statement:-

"In the past, I brought it to the hospital when I was 12 years old or younger. So there is no charge. 
"... He is a classmate near the CRC, he gets an allowance so that's wrong. Every month MYR120 to MYR 150 is like that. But every 3 months only enter the account. But we send our schools to pay MYR 20 to MYR 25 a month like that, but CRC deducts every month from the allowance. " (Informant A)

Apart from that, informant $\mathrm{C}$ also does not need financial support because he has a strong financial system and has only one child, Aiman, who is a learning disabilities person in the autism category and is 24 years old. This is because, the informant and his wife, both are still working and the informant had just received a private pension last year. However, these informants need other support depending on their child's condition. The following is the informant's statement:

"... If in terms of finances, in shaa Allah there is no problem because I have just had a private pension and my epf is still a lot, so now I take more time to manage Aiman."

"Aiman's mother is a teacher."

"After all, Aiman's age has increased to 24 years old. If I send him there [the autism center], it's a bit late, now if I think about Aiman, if he gets a job opportunity, it's ok " (Informant C)

\section{iii- Information Support}

Information support is one of the necessary support. According to the informants, information is important to determine their direction until the end of their lives. This is because, information support includes the provision of information that can help individuals solve problems. The following are excerpts from the interview:

"... CRC also has a social, like communication with outsiders, all this time they only sit with family members, he has no communication with outsiders, so when he hangs out near CRC, he has very little change."

(Informant D)

"... Recently, the CRC has given a proposal, the CRC wants to make an learning disabilities entrepreneur project and wants to give Aiman a job there, where he wants to give a daily salary, the proposal is good, I agree but now there are no signs of the project being made , I want to ask but feel free."

(Informant C)

\section{iv- Psychosocial Support}

Psychosocial support is also an important aspect in the life of the informant because it involves the well-being of the caregiver in order to create well-being in the life of their learning disabilities children. As is well known in psychosocial theory each age has its own roles and conflicts. However, around the age of 20 to 59 years is the phase of each individual will be more focused on parenting, employment, and hobbies. In addition, in this phase they will do their best to do various ways to get more money for the family and so on. If successful at this level, they will feel like contributing or producing something to the family and community. However, if you fail to go through this stage, you will feel unproductive and undeveloped. It will then create psychological problems on these caregivers for feeling that unproductive. Therefore, all informants are in their 30 s to 57 years. Here are some excerpts from the interview. 


\section{"... I used to work but after 2 children, I quit and became a housewife." (Informant A)}

"... First of all, it was when he was 2 years old like that, I quit my job here, I can't let people say me time with friends, can't go out shopping, everything can't be because he will stick with me for 24 hours. " (Informant B)

"... My hopes for him are not much, as long as he can be independent, can take care of himself, I'm grateful." (Informant D)

However, it was different for informant $\mathrm{C}$ who often repeated the word shame because his son was still at the same stage. This informant assumed that he was less clear with his future, thus somewhat disturbing his psycho-social. According to informant $C$ as well, even though he retired last year, he also worked part time and it was to some extent due to his son who had to be taken care of as he could no longer work full time. In fact, every time informant C's child is absorbed into the job, it will only last for 3 months. It to some extent put pressure on informant $C$ and wife. Due to that, there was embarrassment on informant $C$.

\section{"... The family asks a lot about his future, so I sometimes feel embarrassed."}

In conclusion, social support is an important aspect that involves the need for emotional support, instrumental support, information support and psychosocial support. Social support from people around them can help them to cope with their life. This support is able to provide protection and improvement of health through the psychological life of the caregiver when the caregiver experiences conflict disorders in life. In fact, it can increase self -esteem, value and self -confidence as well as well -being in life. Social support is an aspect that needs to be reviewed as it is described as both a buffer from life stress and also as an agent of promoting health and well-being. Research has shown that social support plays an important role in managing psychological problems. Lack of social support has been found to be one of the factors leading to many problems (Zakaria et al., 2019).

\section{Conclusion}

This study was conducted to examine the social support needs of caregivers with learning disabilities in the Community Rehabilitation Centre. Thus, the results of interviews with caregivers who are informants of the study to some extent show that the diversity of backgrounds shows differences in life patterns and care of learning disabilities. For example below 40 families group, dependents of family household, and family expenses. This is because, the researcher has interviewed as many as four informants who are learning disabilities caregivers and can identify the types of learning disabilities who are cared for by informants such as learning disabilities with autism, down syndrome and slow learner. In fact, each of these problems requires different care and different stress. This is based on the age level of the disabled because it is based on the needs of each age group in life. These age differences focus on different problems. For example, the problem of job opportunities, the problem of the disabled self, the problem of unable to afford therapy, the problem of family acceptance and so on. Researchers can identify that the problems that occur in the management of learning disabilities are involving macro, micro and mezzo between the caregiver of disable person and learning disabilities. This is because, the environment is a major thing in an individual's life. 


\section{Acknowledgement}

This study has the cooperation with Universiti Kebangsaan Malaysia under internal research grant (GGP-2020-010).

\section{References}

Amin, A. S., Mat, H. A., \& Manap, J. (2020). Perkhidmatan sokongan bagi keluarga yang mempunyai anak masalah pembelajaran di luar bandar. Jurnal Psikologi Malaysia, 34(3), 28-41.

Amin, A. S., Manap, J., \& Akhir, N. M. (2016). Peranan keluarga dalam kehidupan kanak-kanak kurang upaya Malaysia. Akademika, 86(1),21-30.

Aun, N. S. M., \& Abdullah, H. (2015). Strategi daya tindak dan program sokogan sosial untuk penjaga tidak formal. Journal of Social Sciences and Humanities, 10(1),170-183.

Aun, N. S. M., Bakar, S. H. A., \& Abdullah, F. (2012). International Conference on Social Sciences and Humanities: Mengupayakan Penjaga dan Penjagaan Tidak Formal untuk Keluarga.

Brannon, C., \& Feist, J. (2004). Health psychology: An introduction to behaviour and health. Singapore:Thomson Wadsworth

Christin, E. (2015). Strengths and challenges faced by school-aged children with unilateral cerebral palsy. Developmental Neurorehabiliatron, 30(20), 1-9.

Cuzzocrea, F., Larcan, R., Costa, S., \& Grazzano. (2014). Parent's competence and social skills in siblings. Social berhavior and personality, 42(1),45-58.

Cuzzocrea, F., Larcan, R., \& Westh, F. (2013). Family and parental functioning in parents of disabled children. Nordic Psychology, 65,271-287.

Mahpis, N., \& Akhir, N. M. (2020). Hubungan Sokongan Sosial Terhadap Kemurungan Dalam Kalangan Pelajar. Jurnal Wacana Sarjana, 4(2), 1-10.

Merriam, S. B. (1997). Qualitative Research and case study Applications in Education. San Francisco: Jossey-Bass.

Mohamad, M. S., \& Rosdi, N. N. A. (2018). Hubungan antara tingkah laku keibubapaan, tekanan psikologikal dengan tahap kesihatan mental dalam kalangan penjaga kanakkanak autisme. Jurnal Psikologi Malaysia, 32(4),123-132.

Mohamad, M. S., Abdullah, F., \& Zain, F. M. (2018). Empowering Informal Care Givers Across Gender. Humanisma-Journal of Gender studies, 2(2), 148-157.

Nestmann, F., \& Hurrelmann, K. (1994). Child and adolescent research as a challenge and opportunity for social support theory, measurement, and intervention: and vice versa. In F. Nestmann \& K. Hurrelmann (Eds.), Social networks and social support in childhood and adolescence (pp. 1-22). New York: Walter de Gruyter

Person with Disabilities Act- Akta Orang Kurang Upaya. (2008). Malaysia.

Santamaria, F., Cuzzocrea, F., Guglian Dolo, M. C., \& Larcan, R. (2012). Marital satisfaction and attribution style in parents of children with Autism spectrum disorder: Down syndrome and non-disabled children. Life span and Disability, 15, 19-37.

Sivabalan, T., Zakaria, E., \& Amin, A. S. (2018). Meneroka Strategi Daya Tindak Golongan Ibu Dalam Menjaga Anak Kurang Upaya Kategori Cerebral Palsy. Akademika, 88(2), 121134.

Social Welfare Department Report. (2018). Putrajaya. Malaysia.

Zakaria, M. A., Yusof, F., \& Deraman, S. (2019). Hubungan sokongan sosial dan pengertian hidup dalam kalangan pelajar di kolej kemahiran tinggi mara, Masjid Tanah. Malaysian Journal of Social Sciences, 4(1), 44-53. 